УДК 624.131

\title{
ОЦЕНКА ИНЖЕНЕРНО-ГЕОКРИОЛОГИЧЕСКИХ УСЛОВИЙ БЕРЕГОВОГО НЕФТЕГАЗОКОНДЕНСАТНОГО МЕСТОРОЖДЕНИЯ
}

\section{Строкова Людмила Александровна',}

strokova@sibmail.com

Пургина Дарья Валерьевна',

purgina_darya@mail.ru

Галеева Эльмира Ильдаровна',

holikaholika55@mail.ru

\author{
Курчатова Анна Николаевна², \\ kanni@igig.tgngu.tyumen.ru \\ ' Национальный исследовательский Томский политехнический университет, \\ Россия, 634050, г. Томск, пр. Ленина, 30. \\ 2 Субарктический научно-учебный полигон ТюмНЦ СО РАН - ТюмГНГУ, \\ Россия, 625000, г. Тюмень, ул. Володарского, 56.
}

\begin{abstract}
Актуальность исследования обусловлена необходимостью оценки существующих инженерно-геологических условий, процессов и опасностей, а также связанных с ними рисков и воздействий в отношении предполагаемого использования участка Берегового месторождения Пуровского района Ямало-Ненецкого автономного округа. Необходимым предварительным этапом при разработке проекта обустройства нефтегазоконденсатного месторождения является анализ данных территории строительства. Цель работы: построение карты инженерно-геологических условий территории месторождения для оценки состояния и прогноза изменений инженерно-геологических условий по результатам проведенных инженерно-геологических изысканий.

Объектами исследования являются компоненты геологической среды, рассматриваемые при проектировании освоения Берегового месторождения.

Методы исследования: анализ материалов инженерно-геологических изысканий, детальный литолого-генетический анализ территории, учет закономерностей пространственной изменчивости основных показателей инженерно-геологических условий (состав пород, температура грунтов, характер распространения многолетнемерзлых пород, инженерно-геологические процессы).

Результаты. На основе дешифрирования космоснимка территории выделено шесть типов местностей: А (озерно-болотный); Б (хасырейный); В (приречный); Г (холмисто-увалистый); Д (линейно-грядовый) и Е (техногенные грунты). Результаты полевых работ и лабораторных исследований физико-механических свойств грунтов позволили детализировать предварительную оценку инженерно-геокриологических условий. Основная часть трассы проходит по приречному типу местности В. Наиболее неблагоприятными для строительства сооружений и прокладки трубопровода являются типы местности: А (встречается локально в низинах, представлен болотами с мощностью торфа до 2,2 м) и Б (имеет широкое распространение, представлен заболоченными участками, сложенными глинистыми грунтами с отсутствием поверхностного стока), типы Ги Д по трассе не встречены. По результатам выполненных работ рекомендовано размещать площадки строительства и трассы линейных сооружений на хорошо дренированных суходольных участках распространения талых грунтов.
\end{abstract}

\section{Ключевые слова:}

Грунт, многолетнемерзлые грунты, опасные криогенные процессы, инженерно-геокриологическое картографирование, инженерно-геологические условия.

\section{Введение}

Инженерно-геологическим исследованиям Западно-Сибирской плиты посвящены работы многих российских исследователей - В.Т. Трофимова, Г.А. Голодковской, Д.С. Дроздова, Г.А. Сулакшиной и ряда других [1-5]. Результатами этих исследований явилось установление основных инженерно-геологических и геокриологических закономерностей региона, в частности закономерностей формирования состава, состояния, физико-механических свойств пород. В работах С.Н. Титкова, Ф.М. Ривкина и др. [6, 7] рассмотрены методики геокриологического районирования зон линейных объектов нефте- и газопроводов; показано, что главными факторами природной среды, влияющими на формирование специфики геокриологических условий в исследованном регионе, является характер рельефа, распространение многолетнемерзлых грунтов (ММГ), их льдистость, пораженность территории опасными криогенными процессами, приуроченность различных типов процессов к определенным формациям и геолого-генетическим комплексам пород. В настоящей работе рассматриваются инженерно-геокриологические условия территории нефтегазоконденсатного месторождения Берегового, расположенного в зоне распространения многолетнемерзлых грунтов, определяется устойчивость геологической среды к природным и техногенным процессам, которые могут возникнуть в период строительства и эксплуатации трубопроводной системы. 
Целью является построение инженерно-геологических карт территории месторождения для оценки состояния и прогноза изменений инженерно-геологических условий по результатам проведенных инженерно-геологических изысканий.

Для достижения поставленной цели необходимо выполнить анализ результатов инженерно-геологических изысканий; типизацию инженерно-геокриологических условий; выделение участков с развивающимися (или потенциально опасными) негативными инженерно-геокриологическими процессами, такими как оползнеобразование, эрозия, термоэрозия, термокарст, морозное пучение и пр.

\section{Характеристика Берегового нефтегазоконденсатного} месторождения

Береговое месторождение находится на территории Пуровского района Ямало-Ненецкого автономного округа в $30 \mathrm{kм} \mathrm{юго-восточнее} \mathrm{от} \mathrm{п.г.т.}$ Уренгой. Месторождение открыто в 1982 г., имеет площадь $600 \mathrm{kм}^{2}$. Согласно принятому нефтегазогеологическому районированию, Береговое месторождение приурочено к юго-западной части Тазовского нефтегазоносного района Пур-Тазовской нефтегазоносной области. На месторождении открыто 34 залежи углеводородов в 21 пласте. Коллектором являются песчаники с линзовидными прослоями глин и известняков. Этаж промышленной нефтегазоносности составляет более 2,5 км. Запасы газа составляют более 300 млрд $\mathrm{m}^{3}$, газового конденсата - 0,991 млн т, нефти - 9,035 млн т. Месторождение относится к классу крупных, характеризуется сложным геологическим строением, обусловленным обстановками формирования коллекторов и тектогенезом.

В 1998 г. ОАО «Сибнефтегаз» приобрело лицензию на право пользования недрами Берегового участка и подписало лицензионное соглашение. На первом этапе освоения месторождения произведено обустройство сеноманской газовой залежи. Залежи сеноманского газа располагаются на глубине 800-1700 м, представляют собой главным образом скопления метана. Гораздо ниже, через несколько ярусов после сеноманского газа, запасы которого постепенно истощаются, расположен валанжинский ярус. Валанжинский газ располагается на глубине 1700-3200 м и отличается значительным содержанием этана, пропана и газового конденсата. Валанжинский ярус является частью неокомского надъяруса. Объектом исследований геологов до сих пор являются и ачимовские отложения, запасы газа которых также значительны. Ачимовский газ характеризуется глубиной залегания порядка 4000 м, более сложным геологическим строением, аномально высоким пластовым давлением и значительным содержанием тяжелых парафинов.

Характеристика природных условий территории месторождения

Климат района континентальный, характеризуется долгой холодной зимой и коротким летом.
Среднегодовая температура воздуха составляет $-7,5{ }^{\circ} \mathrm{C}$. Переход температуры через $0{ }^{\circ} \mathrm{C}$ происходит весной до второй половины мая, а осенью - в начале октября. Устойчивый снежный покров сохраняется в течение 220-230 дней - с середины сентября до начала мая [8]. Среднегодовое количество осадков составляет более 44 мм. Число дней со снежным покровом - более 200.

Территория до 70 \% покрыта лесом средней густоты. Растительность, характерная для границы зон тундры и лесотундры, представлена: хвойными породами, широким распространением мхов и лишайников. Значительные площади занимают низинные болота и торфяники [4]. Залежи торфа приурочены к котловинам спущенных озер (хасыреям), приозерным понижениям и ложбинам стока.

\section{Геоморфология}

В геоморфологическом отношении территория Берегового месторождения расположена в западной припуровской части обширного Пур-Тазовского междуречья. Она принадлежит бассейну правых притоков р. Пур от низовьев рек Пякупур и Айваседапур на юге до широты устья р. Евояха [4]. По центральной части месторождения протекает р. Большая Хадырь-Яха с юго-востока на северозапад. На месторождении протекают притоки р. Бол. Хадырь-Яха, р. Лангъ-Яха и р. Вентоко-Яха шириной русловой части до $30 \mathrm{M}$ и поймой до 600 м. Отметки по месторождению колеблются от 15 до 55 м.

Главной рельефообразующей силой, создавшей основные черты рельефа северной части ЗападноСибирской низменности, является деятельность моря и рек. Территория месторождения представляет собой полого снижающуюся в сторону Карского моря абразионно-аккумулятивную равнину с общим наклоном к северу и западу. Формирование современного рельефа началось после спада Ямальской трансгрессии и связано с развитием неотектонических структур и проявлением экзогенных процессов, рельефообразующей аккумуляции в верхнечетвертичное и современное время. Выделенные геоморфологические уровни в зависимости от своего происхождения объединены в три типа равнин: морского, озерно-аллювиального и аллювиального генезиса.

В северной части Пур-Тазовского междуречья развита четвертая лорская терраса. Поверхность террасы плоская, расчленена долинами дренирующих ее рек. Содержащаяся в осадках морская фауна, по определению С.Л. Троицкого, характерна для казанцевских отложений, которые, по мнению И.Л. Кузина (1963), завершают разрез осадков Ямальской трансгрессии [9].

Развитие гидрографической сети северной части низменности началось с отступания моря, сопровождавшееся некоторыми задержками, во время которых в долинах рек были сформированы следующие эрозионно-аккумулятивные уровни: III, II и I надпойменные террасы и пойма. 
Третья надпойленная терраса очень широко развита в средней части Пур-Тазовского междуречья. Плоская поверхность террасы изрезана густой сетью долин притоков основных рек, что придает ей характер полого увалистого рельефа. Образование этой своеобразной террасы происходило в условиях большого обводнения территории, когда в широких речных долинах существовал и речной, и озерно-болотный режим. На поверхности третьей надпойменной террасы широко развиты насаженные формы рельефа, образование которых связано с деятельностью многолетней мерзлоты бугры пучения и термокарстовые просадки, занятые озерами и болотами.

Вторая надпойленная терраса занимает сравнительно большие площади в долинах крупных рек. Высота ее 18-25 м. На поверхности террасы развиты редкие бугры пучения, просадочные западины и закрепленные древние эоловые бугры.

Первая надпойленная терраса распространена небольшими фрагментами вдоль рек. Высота ее 8-12 м. Поверхность террасы ровная. На участках развития бугров пучения и просадочных западин она приобретает слабоволнистый характер. Иногда на ней встречаются эоловые и другие формы микрорельефа. На аэрофотоснимках поверхности этой террасы иногда видны следы блуждания русел рек, переработанные к настоящему времени эрозионно-мерзлотными процессами.

Пойла распространена в долинах всех рек и ручьев района. По высоте и строению поверхности она отчетливо делится на два уровня - высокую и низкую пойму.

Высокая пойла однотипна как в тундровой, так и в лесотундровой и лесной зонах. Высота ее до 5-7 м. Поверхность ее обычно ровная, количество стариц и вееров блуждания русла на ней значительно меньше, чем на низкой пойме. Широко развиты на поверхности высокой поймы бугры пучения и просадочные западины.

Низкая пойла, высотою до 2,5-3 м, по своим морфологическим особенностям подразделяется на два типа. Пойма первого типа представляет собой обширные песчаные поля, лишенные растительности, что благоприятствует образованию эоловых бугров и западин выдувания. Низкая пойма второго типа широко развита в долинах рек лесотундры и северной тайги. Поверхность ее обычно покрыта густой кустарниковой и древесной растительностью.

В целом рельеф территории равнинный, но имеется ряд специфических форм неровностей поверхности, например, различные типы бугристых торфяников, достигающие высоты 1-5 м. Широко распространены термокарстовые явления, при этом наиболее часто встречаются формы, возникшие при вытаивании сегрегационных повторножильных и инъекционных льдов. Характер современного микро- и мезорельефа определяют криогенные и посткриогенные процессы, связанные с существованием многолетней мерзлоты. Широко развитые процессы заболачивания приводят к выравниванию микропонижений за счет нарастания торфяников.

\section{Геологическое строение}

Береговое месторождение расположено в северной части Западно-Сибирской плиты. Породы складчатого основания являются разновозрастными и слагают блоки с карельским, байкальским, салаирским и герцинским фундаментом. Согласно тектонической схеме платформенного чехла, район исследований расположен в пределах крупнейшей надпорядковой структуры - Надым-Тазовской синеклизы, в составе которой выделены чередующиеся положительные и отрицательные структуры I порядка, ориентированные в субмеридиональном направлении [10]. На территории Берегового месторождения к таким структурам относится Нижнепуровская впадина, являющаяся северным продолжением Пуровского мегапрогиба, расположенного в зоне Уренгойско-Колтогорского глубинного разлома. Она осложнена более мелкими структурами - элементами II и III порядка.

На Береговом месторождении чехол сложен осадочными толщами триасового, юрского, мелового и палеогенового возраста. Мощность чехла составляет 5,8-6,0 км.

Отложения четвертичной системы морского, озерно-аллювиального, озерного, аллювиального, болотного и смешанного происхождения [9] pacпространены сплошным покровом толщиной в десятки метров на размытой поверхности континентальных пород палеогена.

Казанцевский горизонт. К данному горизонту отнесены аллювиально-морские отложения четвертой террасы, представленные суглинками, супесями, песками четко-, горизонтально- и косослоистыми, с незначительным содержанием гравийно-галечниково-валунного материала. Мощность отложений 30-40 м.

Ерлаковский горизонт. К данному горизонту отнесены озерно-аллювиальные отложения третьих надпойменных террас (la ${ }^{3} \mathrm{III}$ er), характеризуется большой пестротой осадков, от руслового аллювия до озерно-болотных разностей. В некоторых полных разрезах можно выделить русловую, пойменную и озерную фации. Обычно в базальной части (до 3-5 м) преобладают мелко- и среднезернистые пески, отдельными линзами крупнозернистые, с включениями гравия и гальки кварцевого состава. Характерна четкая косая и перистая слоистость. Средняя часть разреза (пойменная фация) имеет мощность до 6-8 м и представлена пылеватыми и мелкими песками, часто оторфованными с прослоями супесей и суглинков. Озерная фация сложена суглинками, реже глинами, содержащими прослои мелкого песка. Мощность обычно колеблется от 0,5 до 3,0-3,5 м, иногда достигая 6-8 м и более. Судя по данным спорово-пыльцевого анализа [10], климатические условия времени формирования отложений в рассматриваемой ча- 
сти района были суровыми, а растительность представлена березово-ольховыми зарослями с незначительной примесью хвойных. Среди трав отмечены ксерофитные виды и растения прибрежно-водных местообитаний, среди спор доминируют Sphagnum, Polypodiaceae, Lycopodium. Мощность озерно-аллювиальных отложений третьей террасы составляет 10-22 м.

Каргинский горизонт. Озерно-аллювиальные отложения вторых надпойменных террас (la²IIIkr) развиты в долинах практически всех крупных и средних рек района. Аллювиальная фация представлена мелко- и среднезернистыми песками, характерны редкие включения гравия и гальки кварца, растительные остатки разной степени сохранности. В песках отчетливо видна косая или линзовидная слоистость. Озерная фация (верхние 1-3 м) представлена иловатыми песками со слабозаметной слоистостью субгоризонтальной или волнистой, с отдельными прослоями $(0,2-0,5$ м) и линзами супеси и, реже, суглинка. Возраст озерноаллювиальных отложений вторых надпойменных террас определяется их положением в сводном разрезе долинного комплекса. Имеющиеся немногочисленные данные спорового и пыльцевого анализа позволяют предполагать, что в период их формирования существовали ландшафты тундры и лесотундры. Д.В. Назаровым (2011 г.) в верховьях р. Табъяха из аллювия второй террасы получены OSL даты - 37,1; 31,3 и 24,2 тыс. лет, что не противоречит отнесению этих отложений к каргинскому горизонту. В т. н. 0113 по образцу торфа, отобранного из аллювия второй террасы, в Центре изотопных исследований ВСЕГЕИ получена радиоуглеродная дата $33900 \pm 1400$ тыс. лет. Мощность лимно-аллювия второй террасы изменяется от 4-10 м в долинах мелких водотоков до 20-22 м в низовьях Пура [10].

Аллювиальные отложения первой надпойленной террасы (а $\left.{ }^{1} \mathrm{III}-\mathrm{H}\right)$ (верхний неоплейстоцен сартанский горизонт-голоцен) сложены в основном песками мелко- и среднезернистыми, часто пылеватыми, с прослоями супесей и суглинков. Мощность отложений составляет 2-5 м. Практически повсеместно аллювий представлен кварцевыми песками мелко- и среднезернистыми, иногда крупными с единичными прослоями и линзами супеси и оторфованного буровато-серого суглинка. Последние, вероятно, отвечают старичной фации $(2-4$ м). Русловые и пойменные фации аллювия обычно распознаются по наличию в песках следов косой и линзовидной слоистости, тонких прожилков растительного детрита, торфа или захороненных обломков древесины различной степени разложения. В основании разреза иногда фиксируются скопления гравийно-галечного материала и разнозернистых песков. Предполагается, что в пределах долин пойменные (половодные) и старичные фации развиты лишь в низовьях крупных рек, где их суммарная мощность не превышает 5-6 м, а общая мощность достигает 10-12 м [9].
Голоценовые отложения представлены современными осадками различного генезиса.

Аллювиальные отложения пойленных террас $(a H)$ развиты во всех долинах. В наиболее полных разрезах, на фоне преобладания песчаных разностей, возможно расчленение данного осадочного комплекса на три фации: русловую, пойменную и старичную. Отложения русловой фации в основном представлены среднезернистыми песками, иногда мелкими и пылеватыми, с редкими линзами (до 0,5 м) крупного. Характерно обогащение растительными остатками и наличие следов косой слоистости. Мощность аллювия составляет от 8-10 м в долине р. Пур до 3-5 м в долинах малых рек. В составе половодной фации (до 5-7 м) обычно доминируют мелкие и пылеватые пески, часто интенсивно ожелезненные, с прослоями супесей, реже иловатых суглинков и линзами торфа. Пески имеют горизонтальную и пологоволнистую слоистость. Старичным фациям, наиболее широко развитым в долине р. Пур, свойственны супеси с прослоями мелких и пылеватых песков. Возможны линзы темно- и коричневато-серых скрытослоистых суглинков и прослои (0,3-0,5 м) погребенного торфа. Мощность старичной фации аллювия весьма непостоянна и колеблется в пределах 0-5 м. Такой тип разреза характерен для высокой поймы крупных рек. Пойменный аллювий этих рек и аллювий пойм малых водотоков представлен в основном песками мелко-среднезернистыми до крупнозернистых. Основная масса песков развита на речных косах и береговых валах. Для косовых песков отмечена хорошая сортированность и промытость терригенного материала, хотя в них иногда содержатся тонкие наилки суглинка и включения древесно-растительных остатков.

Озерно-аллювиальные отложения имеют ограниченное распространение. В разрезе преобладают пески мелко- и среднезернистые, иногда пылеватые, с прослоями супесей, суглинков. Мощность отложений $3-5$ м.

Болотные отложения представлены торфом разной степени разложения, который перекрывает более древние породы на разных геоморфологических уровнях. Мощность отложений варьирует от 0,5-2,5 м до 2-4 м.

Озерно-болотные отложения приурочены к котловинам осушенных озер - хасыреев, и состоят из торфа и супесей. Мощность торфа составляет от десятков сантиметров до первых метров, супесей обычно 1-2 м.

Пролювиальные образования слагают днища узких логов и балок. Представляют собой супеси с суглинками или их переслаивание. Мощность отложений 1-2 м.

Современные техногенные грунты ( $\left.\mathrm{tQ}_{\mathrm{IV}}\right)$ - насыпные грунты полотна автодорог, площадок имеют локальное распространение. Насыпной грунт состоит из местных песчаных грунтов и представлен песками средней крупности. Насыпные грунты по литологическому составу и генези- 
су имеют одинаковый состав и возраст. Отсыпка произведена сухим способом с уплотнением. По давности отсыпки более 5 лет, по плотности, за счет сосредоточенной нагрузки от движения тяжелой техники, насыпные грунты близки к грунтам в естественном состоянии. Консолидация подстилающих грунтов и процесс самоуплотнения насыпного слоя площадок и автодорог завершены.

\section{Гидрогеологические условия}

В гидрогеологическом отношении Береговое месторождение является частью Западно-Сибирского артезианского бассейна. В вертикальном разрезе этого района выделяются два гидрогеологических этажа: мезозойский и кайнозойский, отличающиеся геологическим строением, условиями питания и водообмена, составом водорастворенных газов, температурным режимом. Для территории месторождения, как и для всего бассейна, характерно наличие мощной глинистой водоупорной толщи, разделяющей их [11].

Мезозойский гидрогеологический этаж включает в себя юрский, неокомский и апт-альб-сеноманский водоносный комплексы.

Юрский гидрогеологический колплекс представлен песчано-алевролитовыми породами береговой, ягельной, котухтинской, тюменской и васюганской свит. Литологически породы комплекса представлены чередованием песчаников, алевролитов, аргиллитов, а в нижней части комплекса в береговой свите представлены грубозернистыми песчаниками, гравелитами с подчиненными прослоями серых уплотненных глин. Вскрытая мощность пород юрского комплекса на месторождении составляет 1569 м. Юрский комплекс характеризуется довольно низкими коллекторскими свойствами, что обуславливает его низкую водообильность. Воды комплекса относятся к хлоридным натриевым или хлоридно-гидрокарбонатым натриевым с минерализацией от 3,6 до 17,9 г/л. Температура подземных вод меняется в значительных пределах и составляет от 98 до $135{ }^{\circ} \mathrm{C}$.

Неоколский гидрогеологический колплекс представлен отложениями мегионской, заполярной и ереямской свит общей мощностью 1250-1365 м. В литологическом отношении комплекс представлен песчано-алевритовыми разностями с прослоями аргиллитов. Песчаные разности обладают лучшими коллекторскими свойствами по сравнению с отложениями юрского гидрогеологического комплекса. По химическому составу воды относятся к хлоридному натриевому, хлоридному натриево-кальциевому или хлоридно-гидрокарбонатному натриевому типам с общей минерализацией, меняющейся в интервале 4,2-23,7 г/л. Водорастворенные газы комплекса имеют метановый состав. Температура пластовых вод меняется от 63 до $96{ }^{\circ} \mathrm{C}$.

Апт-альб-сеноманский гидрогеологический колплекс приурочен к отложениям покурской свиты и представлен чередованием песков, песча- ников и алевролитов. В отложениях комплекса развиты пласты группы ПК, часть из которых продуктивна. К пласту ПК1 приурочена крупная высокодебитная залежь. Кровля покурской свиты залегает на глубинах 1223-1274 м. Мощность комплекса на месторождении составляет 1140-1220 м. Вышележащие турон-палеогеновые глинистые отложения мощностью 770-780 м надежно изолируют комплекс от зоны свободного водообмена. Подземные воды комплекса относятся к хлоридному натриевому типу с величиной обшей минерализации 3,5-22,7 г/л. Водорастворенные газы комплекса имеют метановый состав, газонасыщенность пластовых вод изменяется в интервале 1,5-2,8 л/л. Термобарические условия в пределах апт-альб-сеноманского гидрогеологического комплекса меняются в значительных пределах, так, температура составляет $25-65{ }^{\circ} \mathrm{C}$, а пластовые давления варьируют в интервале от 12 до 24 МПа [11].

Кайнозойский гидрогеологический этаж представлен песчано-алевритистыми и глинистыми отложениями олигоцен-четвертичного возраста и содержит естественные запасы пресных вод. Формирование отложений происходило в условиях свободного водообмена, избыточного увлажнения, тесной связи подземных вод с поверхностными. Мощность составляет до 150-200 м. В отложениях этажа выделяются три водоносных горизонта: казанцевский, салехардский и некрасовский. В гидрогеологическом отношении горизонты на территории Берегового месторождения совершенно не изучены.

В формировании водоносных горизонтов верхнего гидрогеологического этажа большое значение имеют многолетнемерзлые породы. В связи с этим на рассматриваемой территории выделяются подземные воды сезонноталого слоя (СТC), надмерзлотные, межмерзлотные и подмерзлотные.

Пресные воды СТC распространены в местах, где ММП залегают с поверхности. Глубина залегания водоносного горизонта от 0,5 м до нескольких метров. В теплый период года на нормативную глубину сезонного оттаивания 3,0 м водовмещающими породами могут быть насыпные грунты, пески различного литологического состава, супеси и суглинки при условии, если они будут в талом состоянии. Водообильность пород невелика и весьма неравномерна. Коэффициент фильтрации в песках изменяется от 10 до $50 \mathrm{~m} /$ сут, в торфах - от 0,01 до $0,1 \mathrm{~m} /$ сут. Питание горизонта осуществляется за счет атмосферных осадков, поверхностных вод, а также за счет таяния в приповерхностном слое. По химическому составу воды гидрокарбонатные, натриевые, реже кальциевые, пресные и ультрапресные с минерализацией до 50 мг/л.

Надмерзлотные подземные воды приурочены к несквозным таликам под крупными озерами, хасыреями, по долинам ручьев и мелких рек. Водовмещающими породами являются пески, подстилаемые торфом, супесями и суглинками. Толщина горизонта составляет 5-10 м, а под крупными озе- 
рами - 25 м. Водообильность составляет 2-3 л/с при очень ограниченных запасах. Источником питания являются атмосферные осадки, поверхностные воды СТС. По химическому составу воды сульфатно-гидрокарбонатные, магниевые, кальциевые, ультрапресные. Надмерзлотные воды, кроме этого, могут быть приурочены к аллювиальным отложениям, развитым на террасах. Водоносные линзы расположены в прослоях талых песков, толщина которых колеблется в пределах от 2-3 до 5-6 м. По составу воды гидрокарбонатные, кальциевые или натриевые, ультрапресные. Питание осуществляется за счет атмосферных осадков, поверхностных вод.

Межмерзлотные воды приурочены к отложениям некрасовского и салехардского горизонтов. Водоносный средне-четвертичный салехардский горизонт распространен повсеместно. Отложения представлены морскими, ледниково-морскими и прибрежно-морскими песками, слабоглинистыми алевритами с гравием и галькой. Глубина залегания изменяется от 5 до 35 м. Водоносный горизонт напорный. Водоносный олигоцен-нижнечетвертичный горизонт (некрасовский) приурочен к континентальным песчаным отложениям с включениями гравия и гальки. В подошве отложений, примыкающих к глинам тавдинской свиты, горизонт может быть проморожен, а на участках развития крупных болотно-торфяных массивов может находиться в мерзлом состоянии. Водоносный горизонт напорный.

Подмерзлотный водоносный горизонт приурочен, преимущественно, к песчаным отложениям верхнетибейсалинской подсвиты. Водообильность пород незначительная. Воды по составу хлоридные, гидрокарбонатно-натриевые, с минерализацией более 2 г/л.

\section{Инженерно-геологические условия}

Основным этапом изучения закономерностей изменчивости инженерно-геологических условий территории является обобщение данных исследований и составление картографической модели. Источниками информации для составления комплекса карт служили данные: региональных геологических исследований района, результаты бурения 142 инженерно-геокриологических скважин в 2016 г., 15 точек статического зондирования, геокриологической полевой маршрутной съемки вдоль трассы газопровода (с юго-востока на северо-запад по направлению течения р. Бол. Хадырьяха), геофизических исследований (вертикального электрического зондирования и электропрофилирования), дешифрирования топографической основы и космоснимков высокого разрешения. Состав и физико-механические свойства грунтов изучались по 311 пробам нарушенной структуры и 138 монолитам [12].

В строении геологического разреза присутствуют талые и мерзлые грунты. По карте распространения и генетических типов мерзлых пород
(В.В. Баулин, Г.И. Дубиков, 1972) участок входит в зону прерывистого распространения ММП с мощностью верхнего слоя до 50-100 м, глубиной залегания кровли реликтового мерзлого слоя до 70-120 м и подошвы 400 м, в зоне распространения эпигенетических повторно-жильных образований [13].

Для северной и центральной части Пур-Тазовского междуречья до широты среднего течения $\mathrm{p}$. Варга-Сылькы характерно сплошное распространение мерзлых пород на всех геоморфологических уровнях: преимущественно сплошные, монолитные по разрезу мерзлые толщиной от 200 до 300 м. Несквозные талики небольшой мощности существуют только под водоемами - руслами рек и акваториями крупных озер. Толщи многолетнемерзлых пород имеют непрерывный разрез по вертикали от кровли до подошвы [8].

В центральной части Пур-Тазовского междуречья, южнее р. Варга-Сылькы, вплоть до широтного отрезка р. Часельки, мерзлые породы занимают 50 \% территории, распространены в виде отдельных островов, развиты на плоских и бугристых торфяниках и, реже, на заболоченных участках с лесной растительностью, преобладающие пространства междуречий, занятые с поверхности песчаными казанцевыми осадками, являются талыми. Мощность мерзлых пород верхнего слоя колеблется от первых метров до 250 м на крупных массивах с монолитным по разрезу строением мерзлых толщ. Глубина залегания кровли реликтовых мерзлых толщ обычно менее $100 \mathrm{~m}$; их мощность близка к 200 м [8].

По характеру залегания ММП выделяется два типа участков: центральные водораздельные поверхности и краевые участки водораздельных поверхностей, примыкающие к речным долинам. Для центральных заболоченных участков террас свойственно развитие массивов мерзлых грунтов сливающегося типа. Талые зоны возможны под крупными озерами. На краевых, более дренированных участках, покрытых лиственнично-березовым лесом и редколесьем, развиваются ММП несливающегося типа с понижением кровли мёрзлых грунтов до 12 м и более.

Температурный режим многолетнемерзлых грунтов рассматриваемого района разнообразен и зависит от комплекса ландшафтно-геологических условий. Соответственно меняется и среднегодовая температура грунтов по площади области на глубине нулевых годовых колебаний. В заболоченных термокарстовых понижениях, по плоским заболоченным берегам озер и хасыреев, на участках грядово-мочажинных болот среднегодовая температура грунтов понижается до $-1,2 \ldots-1,8{ }^{\circ} \mathrm{C}$, на залесенных поверхностях средние температуры мерзлых участков близки к нулю. Широко развиты процессы пучения, термокарста, на юге встречаются новообразования ММП.

Разрез по трассе до изученной глубины $17 \mathrm{~m}$ представлен преимущественно талыми грунтами 
[12]. Мерзлые грунты встречены локально в девяти скважинах. На участках с многолетнемерзлыми грунтами были проведены замеры температуры грунтов (10 скважин), средняя температура на глубине нулевых колебаний температур (10 м) составляет минус $1,1^{\circ} \mathrm{C}$. Протяженность участков с ММГ составляет 1073,4 м или 7 \% от общей протяженности трассы газопровода 16,06 км. На участках распространения многолетнемерзлых грунтов

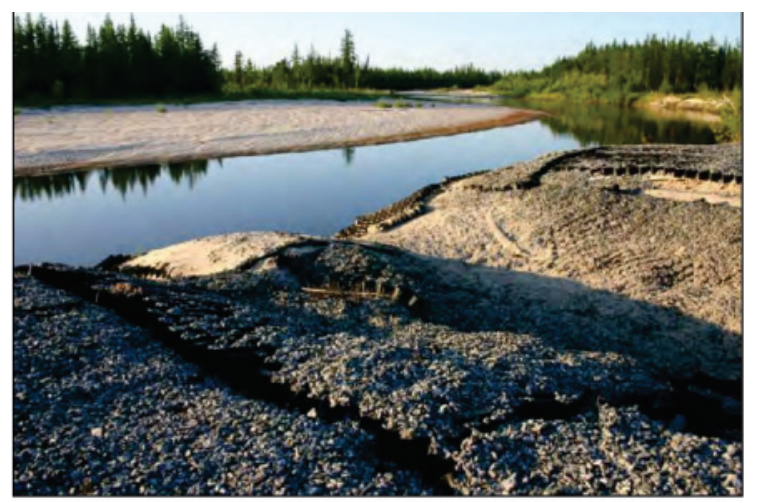

$a / a$

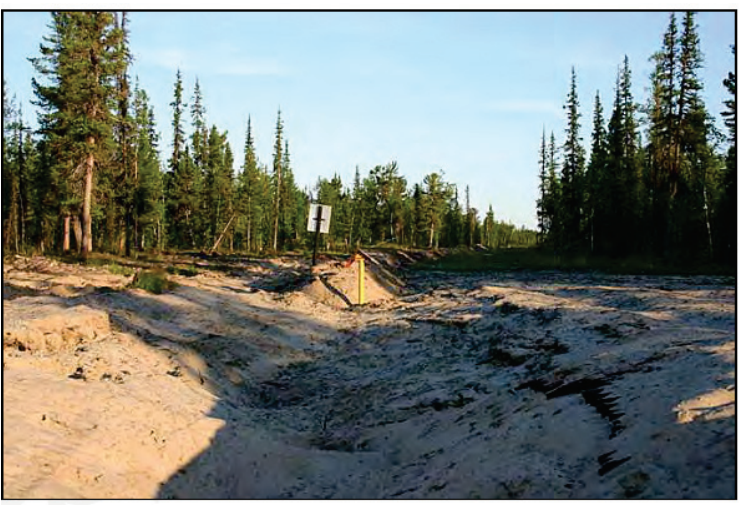

$B / c$

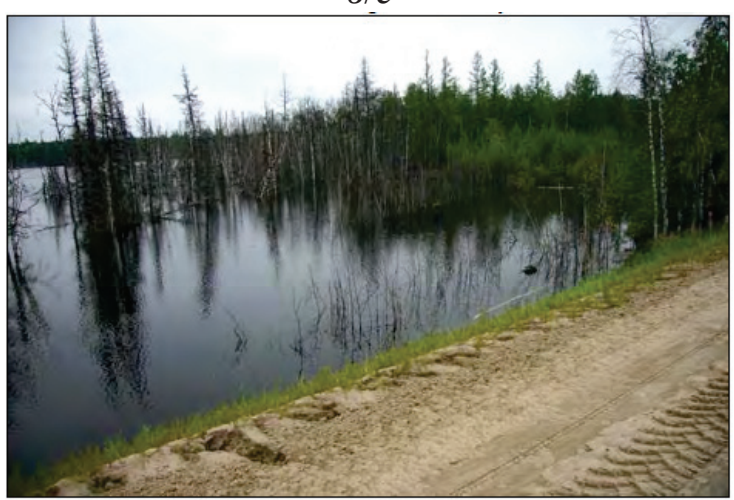

$\partial / e$ встречены три бугра пучения высотой от 1 до 5 м, диаметром от 80 до $120 \mathrm{~m}$.

Согласно СП 14.13330.2014 по карте общего сейсмического районирования России ОСР-2015 $(\mathrm{A}, \mathrm{B}, \mathrm{C})$, территория изысканий попадает в зону самой низкой сейсмичности - 5 баллов и меньше по шкале MSK-64. Среди современных ЭГП (экзогенных геологических процессов) ведущая роль принадлежит криогенным процессам и заболачи-

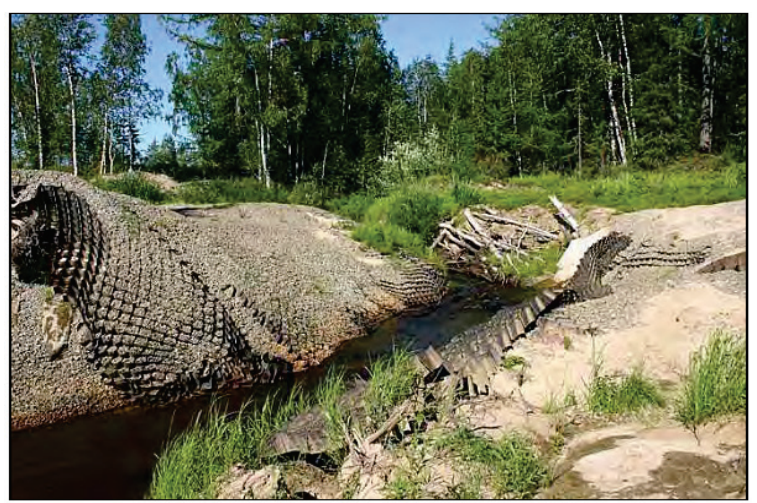

$\sigma / b$

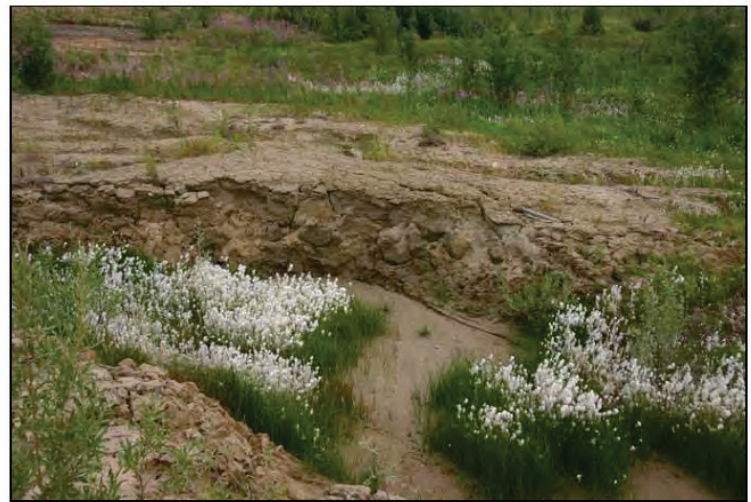

2/d

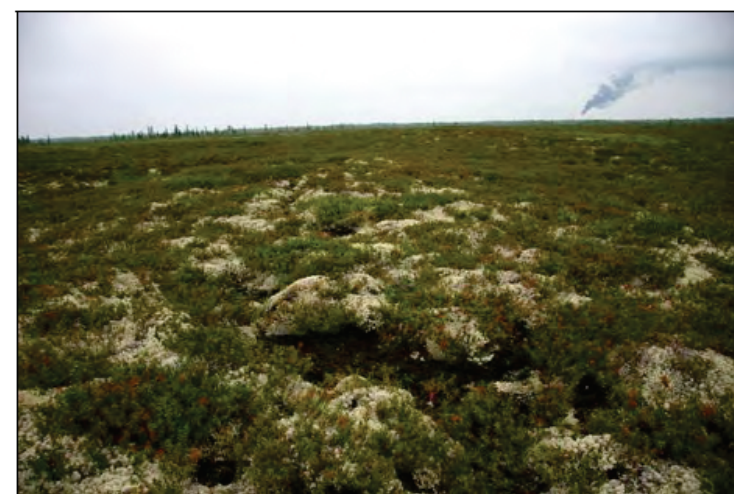

elf

Рис. 1. Экзогенные геологические процессы (фото С.Ю. Кукушкина): разрушение береговой линии: а) р. Малая Хадырьяха; б) р. Нгарка-Саловояха, в месте пересечения с трубопроводом; в) активация линейной эрозии; г) эрозия почв и формирование вторичных осоково-пушицевых сообществ; д) нарушение поверхностного стока и подтопление территории из-за строительства дороги; е) развитие термокарстовых явлений [14]

Fig. 1. Exogenic geological processes (photos were made by S.Yu. Kukushkin): the destruction of the shoreline of small rivers: a) Malaya Khadyryakha; b) Ngarka-Salovoyakha, at the intersection with the pipeline; c) activation of linear erosion; d) soil erosion and formation of secondary sedge-cotton grass biocenosis; $g$ ) violation of the surface runoff and flooding due to a road construction; e) development of thermokarst phenomena [14] 

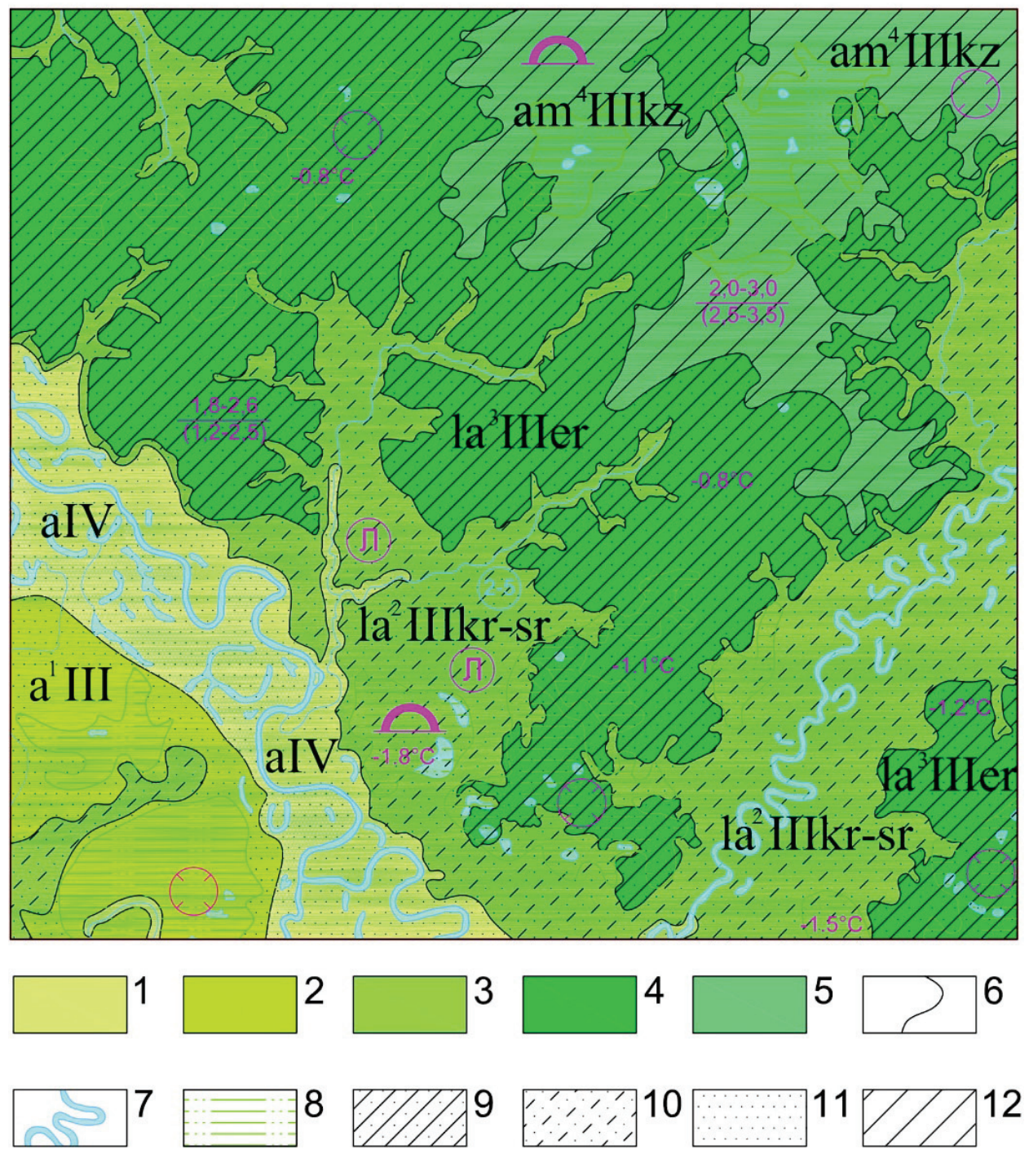

11
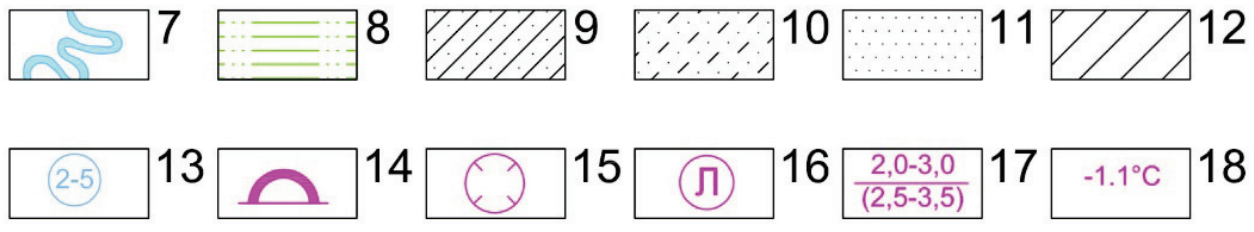

Pис 2. Фрагмент карты инженерно-геологических условий. Масштаб 1:100000. Условные обозначения: 1- современные аллювиальные отложения поймы; 2 - аллювиальные отложения первой надпойменной террасы (a'lllsr-H, верхний неоплейстоцен сартанский горизонт-голоцен); 3 - озерно-аллювиальные отложения второй надпойменной террасы (la²llkr-sr, каргинский горизонт); 4 - озерно-аллювиальные отложения третьей надпойменной террасы (lalller, ермаковский горизонт); 5 - аллювиально-морские отложения четвертой террасы $\left(a m^{4} I l l k z\right.$ казанцевский горизонт); 6 - границы между стратиграфо-генетическими комплексами; 7 - гидрография; 8 - районы развития болот, мощность торфа более 0,5 м; 9 - суглинки, с прослоями песков, супесей; 10 - супеси, с прослоями суглинков, песков; 11 - преимущественно песчаные грунты; 12 - преимущественно глинистые грунты, с прослоями песков; 13 - глубина залегания подземных вод; 14 - морозное пучение; 15 - термокарст; 16 - участки распространения льдистых пород (льдистость за счет видимых включений $\left.i_{i}=0,2-0,4\right) ; 17$ - глубины сезонного оттаивания/промерзания (в скобках); 18 - среднегодовая температура $\mathrm{MM},{ }^{\circ} \mathrm{C}$

Fig. 2. Fragment of the engineering-geological map. Scale 1:100000. Legend: 1 - the floodplain alluvium; 2 - alluvial deposits of the first terrace (a'llIsr-H); 3 - lacustrine-alluvial sediments of the second terrace (la $l|l| k r$-sr, Karginsky horizon); 4 - lacustrine-alluvial sediments of the third terrace (la $a^{3}|l| e r$, Ermakovsky horizon); 5 - alluvial-marine deposits of the fourth terrace (am ${ }^{4}|l| k z$, Kazantsevsky horizon); 6 - boundaries between genetic stratigraphic sequences; 7 - hydrography features; 8 - areas of development of wetlands, thickness of peat more than 0,5 m; 9 - loam with interbedded sand, loamy sand; 10 - sandy loam, with layers of loam, sand; 11 - mainly sandy soils; 12 - mainly clay soils, with interbedded sands; 13 - depth of groundwater; 14 frost heave; 15 - thermokarst; 16 - areas of distribution of icy rocks (volume content of ice at the expense of ice prolayers $\left.i_{i}=0,2-0,4\right) ; 17$ - depth of seasonal thawing/freezing (in parentheses); 18 - mean annual temperature of the permafrost soil mass, ${ }^{\circ} \mathrm{C}$ 
ванию [14]. Процессы заболачивания связаны с рядом природных факторов данного региона, развитию которых способствует плоский слаборасчлененный рельеф, малая глубина эрозионного вреза большинства рек, их замедленный сток, превышение осадков над испарением, наличие многолетней мерзлоты (рис. 1).

По совокупности природных условий (распространение многолетнемерзлых грунтов, развитие болот) категория сложности инженерно-геологических условий участка изысканий - III (сложная) [15, 16].

\section{Инженерно-геокриологическое} картирование территории

Инженерно-геологическому картированию различных регионов, в частности Западной Сибири, посвящены работы Е.М. Сергеева, С.Б. Ершовой (1972), В.Т. Трофимова (1977, 1983, 1985), Г.А. Голодковской $(1981,1989)$, А.С. Герасимовой (1980, 1987), Г.А. Сулакшиной $(1974,1984)$, Е.С. Цоцур (1974), Т.Я. Емельяновой (1984), Л.А. Строковой [17-20]. В их работах предложены принципы, позволяющие в пределах крупного района учесть закономерности распределения региональных и зональных факторов инженерно-геологических условий территории. Такой подход позволяет обособить различные по размерам площади, которые отличаются направленностью геологического развития в плиоцен-четвертичное время, направленностью неотектонических движений, что обусловливает генетико-возрастные особенности рельефа, геологического строения, мерзлотных и гидрогеологических условий, а в их совокупности инженерно-геологические особенности. Поскольку территория характеризуется прерывистым по площади и разрезу распространением многолетнемерзлых пород [21-29], основным методом учета инженерно-геокриологических условий при районировании стал ландшафтно-индикационный метод. В процессе картирования характеристики участков экстраполировались с учетом выявленных закономерностей на основе анализа и дешифрирования топокарт, аэрофото- и космоснимков по комплексу характерных признаков в зависимости от масштаба районирования. Дешифрирование космоснимков с выделением участков проявления опасных экзогенных геологических процессов обусловлено потребностью минимизации рисков воздействия опасных геокриологических процессов, наблюдаемых при освоении месторождений углеводородов.
На рис. 2 представлен фрагмент карты инженерно-геологических условий территории месторождения. Легенда к карте разработана с учетом геоструктурных, инженерно-геологических и геокриологических условий территории. Первый блок легенды содержит информацию о стратиграфо-генетических комплексах четвертичных отложений (первого от поверхности горизонта), их мощности и составе. Их отображению на карте отдано основное изобразительное средство - цвет и его оттенки. Второй блок легенды отдан составу пород, который показан штриховкой. Третий блок легенды посвящен изображению гидрогеологических условий, наиболее распространенным параметром которых является глубина залегания грунтовых вод. Следующий блок легенды посвящен экзогенным процессам и образованиям. На карте они показаны на участках, непосредственно зафиксированных при инженерно-геокриологическом исследовании трассы в процессе полевых работ. Процессы на карте даются внемасштабными общепринятыми значками. Пятый блок легенды отдан показу геокриологической обстановки фиолетовым цветом, как одному из важнейших факторов, определяющих специфику инженерно-геологических условий территории и оказывающих существенное влияние на устойчивость инженерных сооружений. На карте показаны глубины сезонного оттаивания и промерзания (в скобках) пород и льдистость пород, учитывая ее значение при выборе технических решений устройства сооружений. При этом льдистыми считаются супесчано-суглинистые отложения и торф с льдистостью за счет ледяных включений $\left(I_{i}-\right.$ по ГОСТ 25100-2011), равной $0,2-0,4$ и пески с $I_{i}=0,1-0,2\left(W_{\text {tot }}=0,25-0,3\right)$.

Районирование территории трассы газопровода выполнено на основе ландшафтной дифференциации территории по типам местности, отличающимся степенью и характером расчленения рельефа, особенностями распространения ММГ. Выделены следующие типы местностей: А (озерно-болотный) - плоские нерасчлененные заболоченные и заозеренные участки в центральных и тыловых частях равнин и террас, сложенные с поверхности мерзлыми грунтами; Б (хасырейный) - плоские слабо расчлененные ложбины стока, заболоченные участки равнин с обилием спущенных озер (хасыреев) с заглубленной кровлей ММГ или талыми грунтами; В (приречный-дренированный) - плоские, слабо наклоненные к базису эрозии краевые части равнин и террас (бровки склонов долин), сло-

Рис. 3. Дешифровочные признаки геологических процессов: а) космоснимки территории; b) фотографии обследованных участков: I - залесенные участки и редколесья; || - участки проявления термокарста; III - участки активизации эрозионных процессов; IV - торфяники; V - болота

Fig. 3. Interpretive signs of engineering-geological processes: a) satellite imagery of the area; b) photographs of sections: I - forested areas and woodlands; II - areas of thermokarst manifestations; III - areas of erosion intensification; IV - peatlands; V swamps 


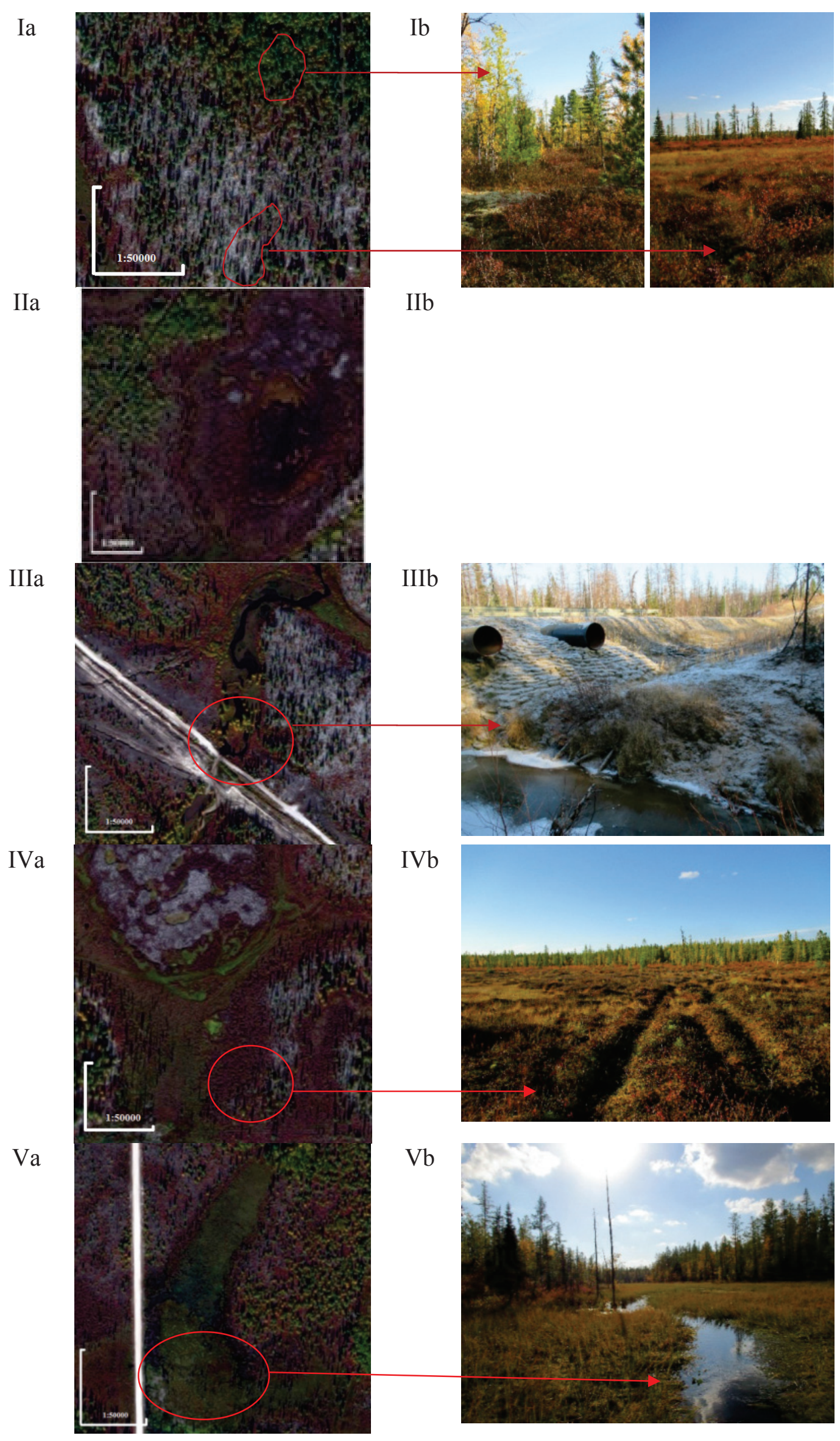


женные талыми песчаными грунтами; Г (холмистоувалистый) - расчлененные поверхности наиболее древних равнин, реже останцы древних отложений среди молодых осадков, сложенные мерзлыми глинистыми грунтами; Д (линейно-грядовый) - участки равнин с частым чередованием низких гряд, сложенных распученными глинистыми породами палеогена и заболоченных межгрядовых понижений, сложенные мерзлыми глинистыми грунтами и супесчаными грунтами; Е (техногенные грунты) - песчаные насыпи автодорог и отсыпки. По результатам дешифрирования космоснимков и инженерно-геологических изысканий выполнена экспертная оценка пораженности территории негативными инженерно-геологическими процессами (в баллах) в зависимости от типа местности (таблица). Баллы распределены следующим образом: 0 - негативные процессы практически отсутствуют по площади; 1 - присутствует местами или локально по площади; 2 - распространены по всей площади.

таблица. Оценка пораженности территории негативными инженерно-геологическими процессами по типам местности

Table. Assessment of the territory damage by negative engineering-geological processes by terrain types

\begin{tabular}{|c|c|c|c|c|c|c|c|c|c|c|c|c|c|c|c|}
\hline \multirow{3}{*}{$\begin{array}{l}\text { Типы местности } \\
\text { Terrain type }\end{array}$} & \multicolumn{14}{|c|}{$\begin{array}{c}\text { Инженерно-геологические процессы } \\
\text { Engineering-geological processes }\end{array}$} & \multirow{3}{*}{ 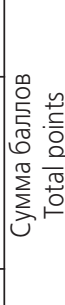 } \\
\hline & \multicolumn{3}{|c|}{ 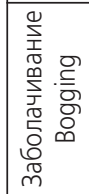 } & \multicolumn{2}{|c|}{ 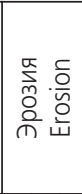 } & & \multicolumn{2}{|c|}{ 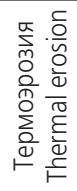 } & \multicolumn{4}{|c|}{ 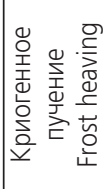 } & \multicolumn{2}{|c|}{ 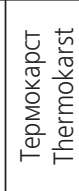 } & \\
\hline & 0 & 1 & 2 & 0 & & & 0 & 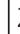 & ( & & 1 & 2 & 0 & $\mid$ & \\
\hline $\begin{array}{l}\text { Озерно-болотный } \\
\text { Lake-marsh }\end{array}$ & & & & & & & & & & & & & & & 6 \\
\hline $\begin{array}{l}\text { Хасырейный } \\
\text { Drained lakes }\end{array}$ & & & & & & & & & & & & & & & 4 \\
\hline $\begin{array}{l}\text { Природно-дрени- } \\
\text { рованный } \\
\text { Naturally drained }\end{array}$ & & & & & & & & & & & & & & & 1 \\
\hline $\begin{array}{l}\text { Техногенные } \\
\text { грунты } \\
\text { Man-made soils }\end{array}$ & & & & & & & & & & & & & & & 3 \\
\hline
\end{tabular}

На рис. 3 представлены дешифровочные признаки геологических процессов: на рис. 3.I - территория леса и редколесья, на рис. 3.II представлена начальная стадия термокарста, на рис. 3.III представлен эрозионный процесс около автодорога вблизи р. Нюдя-Саловояха (техногенные грунты) и показана защита посредством сливных труб, торфяники, на рис. 3.V представлено болото.

Наиболее сложным является тип местности А (5 \% территории), представленный пойменными и заболоченными участками (6 баллов); 16 \% территории характеризуются условиями средней сложности для освоения (4 балла, тип местности Б - хасырейный); простыми для освоения являются типы местности Е (3 балла) и В (1 балл), соответственно 30 и 39 \% протяженности трассы.
Основная часть трассы проходит по дренированному типу местности - В. Данный тип характеризуется преимущественно талыми глинистыми грунтами в верхней части разреза, т. е. в зоне заложения трубопровода. На возвышенных участках в средней части разреза появляются линзы супесей и песков, нижняя часть чаще песчанистая; в понижениях рельефа на поверхность выходят пески и супеси. Мерзлые грунты встречаются локально. Общая протяженность мерзлых грунтов по трассе - 1073,4 м, или $7 \%$, от общей длины участка - 16,066 км.

Неблагоприятными для строительства сооружений и прокладки трубопровода являются типы местности: А (озерно-болотный) и Б (хасырейный). Данные типы характеризуются широким распространением заболоченных участков (мощность торфа 1,2-2,5 м), сложенных глинистыми грунтами с отсутствием поверхностного стока. Общая протяженность составляет 3354,7 м, или $21 \%$, трассы. Типы Г, Д по трассе трубопроводов не встречены.

\section{Заключение}

1. Изучение инженерно-геологических условий месторождения показало, что территория относится к сложной (III) категории. По категории опасности природных процессов территория месторождения относится к опасной по пучению, подтоплению и затоплению, умеренно опасной по сейсмичности. По совокупности проявления природных процессов относится к категории «опасная».

2. Составленная карта инженерно-геологических условий содержат комплексную характеристику геолого-геоморфологических, геокриологических и грунтовых условий исследуемой территории. Карта является основой для разработки карты районирования по условиям строительного освоения. Описаны участки с различной сложностью условий для освоения. Наличие мерзлых, нередко льдистых грунтов, торфов, опасных геологических процессов требует применения комплекса инженерных мероприятий, направленных на предотвращение и снижение их негативных воздействий на инженерные сооружения

3. Рекомендовано размещать площадки строительства и трассы линейных сооружений на хорошо дренированных суходольных участках распространения талых грунтов. На территории месторождения современная тенденция развития толщи ММГ в пределах древних элементов рельефа - на водоразделах характеризуется стабильным состоянием. На молодых элементах рельефа (долинные комплексы крупных рек) происходит активное промерзание талых грунтов, приводящее к появлению новообразованной мерзлоты «перелетков», или к поднятию кровли ММГ на насыпных площадках строительства.

Исследование выполнено в Толском политехническом университете в рамках програмлы повышения конкурентоспособности Томского политехнического университета (средства ВИУ). 


\section{СПИСОК ЛИТЕРАТУРЫ}

1. Геокриологическое районирование Западно-Сибирской плиты / В.Т. Трофимов, Ю.Б. Баду, Ю.К. Васильчук, П.И. Кашперюк, В.Г. Фирсов. - М.: Наука, 1987. - 219 с.

2. Трофимов В.Т., Зилинг Д.Г. 0 роли подхода при инженерногеологическом районировании // Геоэкология. - 1995. № 1. - C. 86-95.

3. Голодковская Г.А. Принципы инженерно-геологической типизации месторождений полезных ископаемых // Вопросы инженерной геологии и грунтоведения. - М.: Изд-во МГУ, 1983. - Вып. 5. - С. 355-369.

4. Дроздов Д.С., Дубровин В.А. Геоэкологические проблемы нефтегазового недропользования в российской Арктике // Криосфера земли. - 2016. - Т. ХХ. - № 4. - С. 16-27.

5. Сулакшина Г.А., Васенева В.А., Цоцур Е.С. Инженерно-геологические условия строительства в районе Советского нефтяного месторождения // Известия Томского политехнического института. - 1975 . - Т. 237. - С. 50-54.

6. Титков С.Н. Инженерно-геокриологическое картографирование при инженерно-геологических изысканиях для строительства магистральных трубопроводов в криолитозоне // Инженерные изыскания. - 2014. - № 4. - С. 42-48.

7. Инженерно-геологическое обеспечение технико-экономического обоснования строительства трансконтинентальных нефтепроводов / Н.В. Иванова, И.Л. Кузнецова, Ф.М. Ривкин, С.Е. Суходольский, И.В. Чехина // Криосфера Земли. 2003. - Т. 7. - № 4. - С. 65-75.

8. Геокриология СССР. Западная Сибирь / под ред. Э.Д. Ершова. - М.: Недра, 1989. - 454 с.

9. Государственная геологическая карта Российской Федерации. Масштаб 1:1000000 (третье поколение). Серия Западно-Сибирская. Лист Q-43 - Новый Уренгой. Объяснительная записка / Ю.В. Брадучан, Е.П. Василенко, А.С. Воронин, Т.Е. Горелина и др. - СПб.: Картографическая фабрика ВСЕГЕИ, 2015. - 320 с.

10. Бочкарев В.С., Боярских Г.К., Нестеров И.И. Тектоническое строение Западно-Сибирской равнины // Тр. ВНИГНИ. - М.: Недра, 1980. - Вып. 218. - С.133-157.

11. Новиков Д.А. Геолого-гидрогеологические условия Берегового нефтегазоконденсатного месторождения // Известия Томского политехнического университета. - 2002. - Т. 305. - № 8. - С. 211-215.

12. Технический отчет по результатам инженерно-геологических изысканий для подготовки проектной и рабочей документации. - Тюмень: 000 «ТюменьПромИзыскания», 2017. - 266 с.

13. Мельников Е.С. Геокриологические условия Западно-Сибирской газоносной провинции. - Новосибирск: Изд-во «Наука», Сибирское отделение, 1983. - 199 с.

14. Кукушкин С.Ю. Индикаторы антропогенной нагрузки на природно-территориальные комплексы при освоении нефтегазоконденсатных месторождений севера Западной Сибири: дис. ... канд. геогр. наук. - СПб., 2016. - 200 с.

15. СП 11-105-97. Инженерно-геологические изыскания для строительства. Ч. 2: Правила производства работ в районах развития опасных геологических и инженерно-геологических процессов. - М.: Госстрой России, 2000. - 94 с.
16. СП 115.13330.2016. Геофизика опасных природных воздействий. - М., 2018. - 56 с.

17. Strokova L.A. Methods of estimating surface settlement during driving of urban tunnels // Soil Mechanics and Foundation Engineering. - 2010. - V. 47. - № 3. - P. 92-95.

18. Пургина Д.В., Строкова Л.А., Кузеванов К.И. Моделирование гидрогеологических условий для обоснования противооползневых мероприятий на участке набережной реки Камы в городе Пермь // Известия Томского политехнического университета. - 2016. - № 1. - T. 327. - C. 116-127.

19. Strokova L.A., Ermolaeva A.V., Golubeva V.V. The Investigation of Dangerous Geological Processes Resulting In Land Subsidence while Designing the Main Gas Pipeline in South Yakutia // IOP Conference Series: Earth and Environmental Science. - 2016. - № 43. - 6 p.

20. Строкова Л.А., Ермолаева А.В. Природные особенности строительства участка газопровода «Сила Сибири» на участке Чаяндинское нефтегазоконденсатное месторождение - Ленск // Известия Томского политехнического университета. - 2015. № 4. - T. 326. - C. 41-55.

21. Geodatabase and WebGIS project for long-term permafrost monitoring at the Vaskiny Dachi research station, Yamal, Russia / Y. Dvornikov, M. Leibman, B. Heim et al. // Polarforschung. 2016. - V. 85 (2), - P. 107-115.

22. Active-layer thickness estimation from X-band SAR backscatter intensity / B. Widhalm, A. Bartsch, M. Leibman, A. Khomutov // The Cryosphere. - 2017. - № 11. - P. 483-496.

23. Circumpolar Mapping of Ground-Fast Lake Ice / A. Bartsch, G. Pointner, M.0. Leibman, Yu.A. Dvornikov, A.V. Khomutov, A.M. Trofaier // Frontiers in Earth Science. - 2017. - V. 5. № 12. - P. 1-16.

24. Activation of Cryogenic Earth Flows and Formation of Thermocirques on Central Yamal as a result of Climate Fluctuations / A. Khomutov, M. Leibman, Yu. Dvornikov, A. Gubarkov, D. Mullanurov, R. Khairullin // Advancing Culture of Living with Landslides. Proceedings of World Landslide Forum / Eds. K. Mikoš, V. Vilímek, Y. Yin, K. Sassa. - Ljubljana, Slovenia, May 29 - June 2, 2017. - Ljubljana: Springer International Publishing AG, 2017. - V. 5. - P. 209-216.

25. Слагода Е.А., Ермак А.А. Дешифрирование экзогенных процессов типичных тундр полуострова Ямал на примере территории района среднего течения реки Юрибей // Вестник Тюменского государственного университета. - 2014. - № 4. P. 28-38.

26. Трофимов В.Т., Красилова Н.С. Инженерно-геологические карты. - М.: КДУ, 2018. - 383 с.

27. Методика мерзлотной съёмки / под ред. В.А. Кудрявцева. М.: Изд-во МГУ, 1979. - 358 с .

28. Методы региональных инженерно-геокриологических исследований для равнинных территорий (ВСЕГИНГЕО). - М.: Недра, 1986. - 207 с.

29. Гафаров Н.А. и др. Использование космической информации в газовой промышленности. - М.: 000 «Газпром экспо», 2010. - 132 c.

Поступила 16.03.2018 2.

\section{Информация об авторах}

Строкова Л.А., доктор геолого-минералогических наук, профессор отделения геологии Инженерной школы природных ресурсов Национального исследовательского Томского политехнического университета.

Пургина Д.В., аспирант отделения геологии Инженерной школы природных ресурсов Национального исследовательского Томского политехнического университета.

Галеева Э.И., магистрант отделения геологии Инженерной школы природных ресурсов Национального исследовательского Томского политехнического университета.

Kурчатова $\boldsymbol{A}$.H., кандидат геолого-минералогических наук, старший научный сотрудник, директор Субарктического научно-учебного полигона ТюмНЦ СО РАН - ТюмГНГУ. 
UDK 624.131

\title{
EVALUATION OF ENGINEERING-GEOCRYOLOGICAL CONDITIONS OF THE BEREGOVOE OIL AND GAS CONDENSATE FIELD
}

Lyudmila A. Strokova',

strokova@sibmail.com

Darya V. Purgina',

purgina_darya@mail.ru

Elmira I. Galeeva',

holikaholika55@mail.ru

\section{Anna N. Kurchatova²,}

kanni@igig.tgngu.tyumen.ru

\author{
National Research Tomsk Polytechnic University, \\ 30, Lenin Avenue, Tomsk, 634050, Russia. \\ 2 Subarctic scientific training range, Tyumen industrial University, \\ 56, Volodarsky street, Tyumen, 625000, Russia.
}

The relevance of the research is caused by the need to assess the existing engineering geological conditions, processes, and hazards, as well as the risks and impacts related to them with respect to the intended use of the site of the Beregovoe Field of Purovsky District, Yamalo-Nenets Autonomous Okrug. A necessary preliminary step in development of the project is the analysis of engineering-geological data of the construction site.

The main aim of the research is to create the engineering-geological map of the deposit for assessing the situation and forecasting the changes engineering geological conditions according to the results of the performed geotechnical investigations.

Objects of researches are surface features and subsurface earth materials for design and construction of the Beregovoe field exploration. Methods: the analysis of engineering-geological surveys, detailed lithological-genetic analysis of the territory, taking into account the regularities of the spatial variability of the main indicators of engineering-geological conditions (composition of soils, their temperature, distribution of permafrost and engineering-geological processes).

Results. The authors identified six types of areas: A (lakes and marshes); B (drained lake); C (riverside); D (hilly ridge); E (linear ridge) and $F$ (man-made soils). The results of the field works and laboratory investigations of geotechnical properties of soils allowed detailing a preliminary assessment of the engineering-geocryological conditions. The main part of the route passes through riparian areas $C$. The most unfavorable for construction of facilities and pipeline are terrain types: A (found locally in the lowlands, represented by marshes with a capacity of peat to 2,2 m) and B (has wide distribution, represented by wetlands, folded clay soils with no surface runoff). The types $D$ and $E$ are not met on the route. We recommend placing the linear structures of pipelines on well-drained upland sites spread thawed soils.

Key words:

Soil, permafrost, dangerous cryogenic processes, engineering-geocryological mapping, engineering-geological conditions.

The research was carried out at Tomsk Polytechnic University within the Program of Enhancing Competitiveness of Tomsk Polytechnic University (VIU funds).

\section{REFERENCES}

1. Trofimov V.T., Badu Yu.B., Vasilchuk Yu.K., Kashperjuk P.I., Firsov V.G. Geokriologicheskoe rayonirovanie Zapadno-Sibirskoy plity [Geocryological zoning of the West Siberian plate]. Moscow, Nauka Publ., 1987. 219 p.

2. Trofimov V.T., Ziling D.G. 0 roli podkhoda pri inzhenerno-geologicheskom rayonirovanii [ $0 \mathrm{n}$ the role of the approach to engineering-geological zoning]. Geoecology, 1995, vol. 1, pp. 86-95.

3. Golodkovskaya G.A. Printsipy inzhenerno-geologicheskoy tipizatsii mestorozhdeniy poleznykh iskopaemykh [Principles of engineering-geological typification of mineral deposits]. Voprosy inzhenernoy geologii i gruntovedeniya [Geology and soil science]. Moscow, Moscow State University Publ. house, 1983. Vol. 5, pp. $355-369$.

4. Drozdov D.S., Dubrovin V.A. Geoecological problems of oil and gas subsoil use in the Russian Arctic. Earth's cryosphere, 2016, vol. XX, no. 4, pp. 14-25.
5. Sulakshina G.A., Vaseneva V.A., Cocur E.S. Engineering-geological conditions of construction in the area of the Soviet oil fields. Bulletin of the Tomsk Polytechnic Institute, 1975, vol. 237, pp. 50-54. In Rus.

6. Titkov S.N. Engineering-geocryological mapping, geotechnical investigation for construction of trunk pipelines in the permafrost zone. Engineering surveying, 2014, vol. 4. pp. 42-48. In Rus.

7. Ivanova N.V., Kuznetsova I.L., Rivkin F.M., Sukhodolsky S.E., Chekina V.I. Engineering-geological provision of feasibility study for construction of transcontinental pipelines. Earth's cryosphere, 2003, vol. 7, no. 4, pp. 65-75. In Rus.

8. Geokriologiya SSSR. Zapadnaya Sibir [Geocryology of the USSR. Western Siberia]. Ed. by E.D. Ershov. Moscow, Nedra Publ., 1989. $454 \mathrm{p}$.

9. Braduchan Yu.V., Vasilenko E.P. Gosudarstvennaya geologicheskaya karta Rossiyskoy Federatsii. Masshtab 1:1000000 (trete po- 
kolenie). Seriya Zapadno-Sibirskaya. List Q-43 - Novy Urengoy [State geological map of the Russian Federation. Scale 1:1000000 (third generation). A Series of West-Siberian. Sheet Q-43-New Urengoy]. St-Petersburg, Cartographic factory VSEGEI Publ., 2015. 320 p.

10. Bochkarev V.S., Boyarskikh G.K., Nesterov I.I. Tektonicheskoe stroenie Zapadno-Sibirskoy ravniny [Tectonic structure of the West Siberian plain]. Moscow, VNIGNI Publ., 1980. Vol. 218, pp. $133-157$.

11. Novikov D.A. Geological and hydrogeological conditions of Beregovoe oil and gas condensate field. Bulletin of the Tomsk Polytechnic University, 2002, vol. 305, no. 8, pp. 211-215. In Rus.

12. Tehnicheskiy otchet po rezultatam inzhenerno-geologicheskikh izyskany dlya podgotovki proektnoy $i$ rabochey dokumentatsii [Technical report on the results of engineering-geological surveys for preparation of project and working documentation]. Tyumen, TyumenPromIzyskaniya Publ., 2017. 266 p.

13. Melnikov E.S. Geokriologicheskie usloviya Zapadno-Sibirskoy ga zonosnoy provintsii [Permafrost conditions of the West Siberian gas-bearing province]. Novosibirsk, S0 RAN Publ., 1983. 199 p.

14. Kukushkin S.Yu. Indikatory antropogennoy nagruzki na prirodno-territorialnye kompleksy pri osvoenii neftegazokondensatnykh mestorozhdeny severa Zapadnoy Sibiri. Dis. Kand. nauk [Indicators of anthropogenic load on natural-territorial complexes in development of oil and gas deposits in the North of Western Siberia. Cand. Dis.]. St-Peterburg, 2016. 200 p.

15. SP 11-105-97. Inzhenerno-geologicheskie izyskaniya dlya stroitelstva. Ch. 2: Pravila proizvodstva rabot $v$ rayonakh razvitiya opasnykh geologicheskikh i inzhenerno-geologicheskikh protsessov [Set of rules 11-105-97. Engineering-geological surveys for construction. P. 2: Rules of works in the area of development of hazardous geological and engineering-geological processes]. Moscow, Gosstroy Rossii Publ., 2000. 94 p.

16. SP 115.13330.2016. Geofizika opasnykh prirodnykh vozdeystviy [Set of rules 115.13330.2016. Geophysics of hazardous natural impacts]. Moscow, 2018. 56 p.

17. Strokova L.A. Methods of estimating surface settlement during driving of urban tunnels Soil Mechanics and Foundation Engineering, 2010, vol. 47, no. 3, pp. 92-95.

18. Purgina D.V., Strokova L.A., Kuzevanov K.I. Modeling hydrogeological conditions for antilandslide measures justification on the plot of the Kama river embankment in Perm. Bulletin of the Tomsk Polytechnic University. Geo Assets Engineering, 2016, vol. 327, no. 1, pp. 116-127. In Rus.

19. Strokova L.A., Ermolaeva A.V., Golubeva V.V. The Investigation of Dangerous Geological Processes Resulting In Land Subsidence
While Designing the Main Gas Pipeline in South Yakutia. IOP Conference Series: Earth and Environmental Science, 2016, vol. $43,6 \mathrm{p}$.

20. Strokova L.A., Ermolaeva A.V. Natural features of construction of the main gas pipeline «The Power of Siberia» on a site Chayandinskoye oil and gas field - Lensk. Bulletin of the Tomsk Polytechnic University, 2015, vol. 326, no. 4, pp. 41-55. In Rus.

21. Dvornikov Y., Leibman M., Heim B. Geodatabase and WebGIS project for long-term permafrost monitoring at the Vaskiny Dachi research station, Yamal, Russia. Polarforschung, 2016, vol. 85, no. 2, pp. 107-115.

22. Widhalm B., Bartsch A., Leibman M., Khomutov A. Active-layer thickness estimation from X-band SAR backscatter intensity. The Cryosphere, 2017, no. 11, pp. 483-496.

23. Bartsch A., Pointner G., Leibman M.O., Dvornikov Yu.A., Khomutov A.V., Trofaier A.M. Circumpolar Mapping of Ground-Fast Lake Ice. Frontiers in Earth Science, 2017, vol. 5, article 12, pp. 1-16.

24. Khomutov A., Leibman M., Dvornikov Yu., Gubarkov A., Mullanurov D., Khairullin R. Activation of Cryogenic Earth Flows and Formation of Thermocirques on Central Yamal as a Result of Climate Fluctuations. Advancing Culture of Living with Landslides. Proceedings of World Landslide Forum. Eds. K. Mikoš, V. Vilímek, Y. Yin, K. Sassa. Ljubljana, Slovenia, May 29 June 2, 2017. Ljubljana, Springer International Publishing AG, 2017. Vol. 5, pp. 209-216.

25. Slagoda E.A., Ermak A.A. Interpretation of exogenous processes in typical tundra of the Yamal peninsula (case study of the district in the middle Yuribey river). Bulletin of Tyumen state University, 2014, vol. 4, pp. 28-38. In Rus.

26. Trofimov V.T., Krasilova N.S. Inzhenerno-geologicheskie karty [Engineering geological maps]. Moscow, KDU Publ., 2018. 383 p.

27. Metodika merzlotnoy semki [Methodology of permafrost survey]. Ed. by V.A. Kudryavtsev. Moscow, Moscow State University Publ., 1979. 358 p.

28. Metody regionalnykh inzhenerno-geokriologicheskikh issledovaniy dlya rauninnykh territoriy [Methods of regional engineeringgeocryological research for lowland areas, VSEGINGE0]. Moscow, Nedra Publ., 1986. 207 p.

29. Gafarov N.A. Ispolzovanie kosmicheskoy informatsii $v$ gazovoy promyshlennosti [Use of space information in the gas industry]. Moscow, Gazprom Expo Publ., 2010. 132 p.

Received: 16 March 2018.

\section{Information about the authors}

Lyudmila A. Strokova, Dr. Sc., professor, National Research Tomsk Polytechnic University.

Darya V. Purgina, postgraduate student, National Research Tomsk Polytechnic University.

Elmira I. Galeeva, student, National Research Tomsk Polytechnic University.

Anna N. Kurchatova, Cand. Sc., executive officer, Subarctic scientific training range, Tyumen Industrial University. 